\title{
Relationship Occupational Health and Safety Promotion between Safety Behavior Production Workers in Palm Plant PTPN IV Kebun Bah Jambi
}

\author{
Halinda Sari Lubis ${ }^{1}$, James Steven F.D ${ }^{2}$ \\ ${ }^{1,2}$ Occupational Health and Safety Department, University of Sumatera Utara, Indonesia \\ Halinda.sarieyahoo.co.id
}

\begin{abstract}
PTPN IV Kebun Bah Jambi is a company that does cultivation and processing of palm fruits. According to PTPN IV Kebun Bah Jambi's report of work accidents, occurred 15 cases of work accidents during the period January 2013-December 2015, that the highest number of accidents occurred in 2015. The most accident happened in the production area and majority accidents causes are unsafe behavior. Certainly, this condition is not as expected because the company has been implementing the health and safety promotion as an attempt to form safe behavior. Design of this research is crossed sectional study that aim to explain the realationship between independent variable (health and safety promotion) with dependent variable (safety behavior) on production workers. Sample in this research are all population that totally 86 workers. The result showed that four or five forms of health and safety promotion had significant relationship with safety behavior, those health and safety communication information, health and safety month activities, supervision and health and safety training based from chi square analytic. Based on the research, suggested to the management of PKS PTPN IV Kebun Bah Jambi to encourage health and safety information updating regularly, promoting health and safety activities and increasing participation of production workers and facilitating them to participate in health and safety training completely, so that can protect all the workers in the workplace.
\end{abstract}

Keywords - Health and Safety Promotion, Safety Behavior

\section{INTRODUCTION}

Government by the Law No. 1 Year 1970 has stated that every worker is entitled to protection of his safety in performing work. This is supported by the Law No. 13 Year 2003 which state the right of worker to receive occupational safety and health protection (article 86 verse 1) being administered through an occupational health and safety scheme to realize optimal productivity.

Accident does not occurred coincidentally but there must be the cause to be investigated, then the corrective actions can be administered to eliminate the causative factor of the accident so it shall not be recur next time. There are two categories of oocupational accident causative factors, which are mechanical and environmental factor and human factor [1]. Research results show $80-85 \%$ accidents caused by human error which is done by everyone involved in the occupational activity. Improvement scheme on this error is continuously sought both from worker and managerial aspects. Improvement scheme is directed more on fixing workers behaviour when performing occupational activity in the company.

Halimah's research, which is held in Bekasi on 86 respondents about factors affecting the safe behaviour, shows significant correlation between safety promotion (external factor) and safe behavior [2]. Sipayung, in his research about the relationship between occupational health and safety promotion and safe behaviour which is held in Simalungun District on 44 respondents shows correlation between OHS Month activity and training and safe behaviour. OHS Month activity is a kind of OSH promotion activity [3].

PTPN IV Kebun Bah Jambi is a palm oil cultivation company which start from pre-nursery until Crude Palm Oil (CPO) and kernel production. The process begins with weighing fresh fruit sign, then sorting station, sterilizer station, thresher station, pressing station and ends in clarification and kernel station. Hazards can be found in occupational activity in every production step which likely become occupational accident risk. According to occupational accident report of PTPN IV Bah Jambi under January 2013 to December 2015 period, there are 15 cases of occupational accident, and the maximum frequency 
occurred in 2015 whereas there must be case reduction because of the OHS promotion in occupational safety and health held by the company. Based on this fact, a research is run to know the relationship between OHS promotion (include OHS information communication, OHS signs, OHS month activity, OHS supervision and training) and worker safety behaviour.

\section{MATERIAL AND METHOD}

The reasearch design is cross sectional design in production section of Palm Oil Factory of PTPN IV Bah Jambi from March to August 2016 with sample size of 86 workers as the total population. Primary data source is obtained by interview using questionnaire about OHS promotion and occupational safety behaviour which is the modification of Sipayung's questionnaire. Measurement uses Guttman Scale with two interval [4]. Independent variable of OHS promotion consists of OHS information communication (4 questions), OHS signs (6 questions), OHS month activity (6 questions), OHS supervision (5 questions), OHS training (4 questions), and behaviour as dependent variable consists of 4 questions with safe and unsafe categories. Data analysis is bivariate using chi square test.

\section{RESULT}

Workers as the sample distributed with maximum age group is on $>47$ years old category $(55,8 \%)$ according to mean value, maximum workers educational level is Senior High School category which are 62 workers $(72,1 \%)$, with maximum working period of more than 24 years category $(53,5 \%)$.

Bivariate analysis result between OHS promotion variable and safety behaviour is performed in this following table 1 .
TABLE I

OF RELATIONSHIP BETWEEN OHS PROMOTION AND WORKERS SAFETY BEHAVIOUR IN PRODUCTION SECTION IN PALM OIL FACTORY OF PTPN IV KEBUN BAH JAMBI.

\begin{tabular}{|c|c|c|c|c|c|c|c|}
\hline \multirow[t]{2}{*}{$\begin{array}{c}\text { OHS } \\
\text { Promotion }\end{array}$} & \multicolumn{2}{|c|}{$\begin{array}{c}\text { Safe } \\
\text { Behaviour }\end{array}$} & \multicolumn{2}{|c|}{$\begin{array}{c}\text { Unsafe } \\
\text { Behaviour }\end{array}$} & \multicolumn{2}{|c|}{ Total } & \multirow[t]{2}{*}{$\mathrm{p}$ value } \\
\hline & $\mathrm{N}$ & $\%$ & $\mathrm{~N}$ & $\%$ & $\mathrm{~N}$ & $\%$ & \\
\hline \multicolumn{8}{|c|}{ OHS information communication } \\
\hline Good & 6 & 7 & 2 & 2,3 & 8 & 9,3 & 0.001 \\
\hline Not Good & 13 & 15,1 & 65 & 75,6 & 78 & 90,7 & \\
\hline \multicolumn{8}{|l|}{ OHS signs } \\
\hline Good & 15 & 17,4 & 41 & 47,7 & 56 & 65,1 & 0.152 \\
\hline Not Good & 4 & 4,7 & 26 & 30,2 & 30 & 34,9 & \\
\hline \multicolumn{8}{|c|}{ OHS month activity } \\
\hline Good & 7 & 8,1 & 3 & 3,5 & 10 & 11,6 & 0.001 \\
\hline Not Good & 12 & 14 & 64 & 74,4 & 76 & 88,4 & \\
\hline \multicolumn{8}{|l|}{ OHS supervision } \\
\hline Good & 7 & 8,1 & 8 & 9,3 & 15 & 17,4 & 0.019 \\
\hline Not Good & 12 & 14 & 59 & 68,6 & 71 & 82,6 & \\
\hline \multicolumn{8}{|l|}{ OHS training } \\
\hline Good & 7 & 8,1 & 4 & 4,7 & 11 & 12,8 & 0.002 \\
\hline Not Good & 12 & 14 & 63 & 73,2 & 75 & 87,2 & \\
\hline
\end{tabular}

Based on the table above, OHS promotion variable which has statistic significant correlation with safety behaviour are OHS information communication, OHS month activity, OHS supervision and training with $p$ value $<0.005$.

\section{DISCUSSION}

From the research result can be obtained the statistically significant correlation between OHS information communication and safety behaviour. This can be obviously seen from workers who inform deficient information and communication which resulting increased probability of occupational accident. In the previous period, information is given only for some workers which are the head of every station, in the form of manual book of OHS Management System. This condition or inadequate way of information sounding resulting on poor information distribution among workers. Information based on library reference is needed as the explanation of occupational safety according to Suma'mur, general 
knowledge can be increased through books, brochures, magazines, etc. Lack of information resulting decreased occupational safety behaviour and opening probability of increased occupational accident.

OHS signs in company in the form of logos or writings placed in the work station are about compulsory Self-Protection Tool usage, prohibition of doing unsafe act, hazardous location, persuative information on OHS applying, fire extinguisher tools information, first aid position information. From the research result is obtained statistically insignificant correlation between OHS signs and safety behaviour. This condition possibly make the workers doesn't pay much attention on the existing signs in working activity. This condition occurred because of not attractive OHS signs.

OHS month activity significantly correlated with safety behaviour, which include OHS flag setting, quiz contest, OHS poster drawing, OHS social action in form of mutual assistance in the factory area with $\mathrm{OHS}$ messages reading. Those are very attractive to workers so that they are accustomed to remember and follow the safe occupational procedures and rules. The result is also supported by an expert Suma'mur that occupational safety needs movement with occupational safety supporting activities which encourage enthusiasm and awareness in doing appropriate occupational safety behavior [1].

Correlation between supervision and safety behaviour are statistically significant. These include supervisor action to watch over the workers in holding their jobdesks routinely and also watch over them during working period. The supervisory relationship with behavioral safety is meaningful statistics in the form of the action part of supervisors monitor workers in carry out her work regularly and monitor the worker in the work during working hours. This allows workers to act carefully and comply with the appropriate safety behaves. According to Ramli, supervisor is the key element in OHS programme because supervisor is a person directly related to the workplace and the workers, he also knows the most about workers and working situation. ${ }^{5}$ According to Bird and Germain in
Halimah, supervision on workers activity is expected to grow obedience and awareness on the importance of occupational safety in performing work [2].

Applied OHS training do not cover the whole work yet. So this condition support bigger proportion of workers doing inappropriate-with-occupational-safety behaviour than workers doing appropriate-withoccupational-safety behaviour. It matches a research result that OHS training is significantly correlated with safety behaviour. According to Ramli, the worker must be trained to work safely because the appropriate-with-OHS working behaviour does not occur automatically, but it proceeds through development and training [6].

\section{CONCLUSION}

The conclusion of this research is that the OHS promotion variable which is significantly correlated with safety behaviour areOHS information communication, OHS month activity, OHS supervision and training. Based on this fact, it is necessary to increase the occupational safety information covering all workers through brochure, in the OHS month activity, together with supervision and OHS training and components include all workers at the beginning of recruitment and re-training to refresh after long period of working.

\section{ACKNOWLEDGEMENT}

This research owes its existence to the help and support of Director of PTPN IV Kebun Bah Jambi by facilitating the interview to the workers.

\section{REFERENCE}

[1] Suma'mur P. K. (2009) Higiene Perusahaan dan Kesehatan Kerja (Hiperkes). CV SagungSeto, Jakarta

[2] Halimah S. (2010)Faktor-faktor yang mempengaru hiperilaku aman karyawan PT. SIM Plant Tambun II tahun 2010. Student paper of FKIK UIN Syarif Hidayatullah at http://repository. uinjkt. ac. id: accessed on March $12^{\text {th }}, 2016$ at 20.00

[3] Sipayung R. T. (2014)Hubungan promosi keselamatan dan ksehatan kerja (K3) dengan perilaku aman (Safe Behavior) pada karyawan bagian produksi pengolahan minyak sawit di PTPN IV Kebun Dolok Ilirtahun 2014. Student paper of FKM USU

[4] Sugoyono (2009) Metode Penelitian Administrasi. Fifteenth Ed. ALFABETA, Bandung

[5] Ramli S. (2010) Sistem manajemen keselamatan \& kesehatan kerja OHSAS 18001. Second Ed. PT Dian Rakyat, Jakarta

[6] PTPN IV (2015) Buku panduan pedoman operasional pengolahan kelapa sawit bagian pengolahan. Medan 
[7] Notoadmodjo (2003) Pendidikan dan peilaku kesehaatan. Rineka Cipta, Jakarta

[8] Republik Indonesia (2003) Undang-undang RI Nomor 13 Tahun 2003 tentang Ketengakerjaan. Sekretariat Negara, Jakarta. 